\title{
Toward an Operational Definition of Consensus
}

\author{
Ole R. Holsti, Duke University
}

Although "consensus" is a key concept in several social sciences, there is very little agreement on how it should be defined. That political philosophers and theorists who have pondered the extent and types of agreement necessary for effective political systems rarely specify the threshold for consensus is not surprising. But even students of voting behavior and public opinion, who use the term extensively, often fail to identify precise levels of agreement necessary to achieve consensus; among those who do, there is a lack of agreement on how high that level should be. This paper attempts to develop an operational definition of consensus based on the level of agreement across two groups - in this case, political parties. A 4x4 matrix yields six distinct levels of agreement ranging from "strong bipartisan consensus" to "strong partisan dissensus." In order to account for variations in response options, four versions are described. Evidence from four nationwide surveys on the foreign policy attitudes of American opinion leaders-conducted in 1976, 1980, 1984 and 1988 - is used to illustrate the scheme.

Consensus: group solidarity in sentiment and belief: a general agreement; unanimity; a judgment arrived at by most of those concerned (Webster's 1986, 279).

As a word, however, "consensus" is like "charisma"-it eludes precise definition. We have an intuitive sense of its meaning, but we do not know exactly what it is (or was), or what it should be. We seem to mean by it some minimum level of agreement on some minimum central policies - or alternatively some central belief system, but we have no clear understanding on how much agreement, among whom, or what subjects, and how it should be measured (Cohen n.d.).

There is widespread agreement among social scientists that "consensus" is a key concept. In his presidential address to the American Sociological Society, Louis Wirth stated that "I regard the study of consensus as the central task of sociology, which is to understand the behavior of men in so far as the behavior is influenced by group life" (quoted in Newcomb $1959,278)$. Although not all would fully endorse Wirth's assessment, many political analysts also have given a central place to the concept of consensus. Political philosophers and theorists have pondered the extent and types of agreement necessary for effective political systems, especially democracies. More empirical studies of voting behavior and public opinion also have used the term extensively. For example, a major impetus to the recent revival of

OLE R. HOLSTI is George V. Allen Professor of International Affairs at Duke University, and is a past president of the International Studies Association.

The American Review of Politics, Vol. 14, Autumn, 1993: 309-339

(C)1993 The American Review of Politics 
interest in public opinion and foreign policy has been a sense that the apparent consensus supporting American foreign policy during the two decades after World War II had broken down by the end of the Vietnam War. ${ }^{1}$ Most analysts also agree that it is useful to identify a hierarchy of levels of consensus. Several of them distinguish between consensus about the basic constitutional framework, procedures, and specific public policy issues (e.g., Graham 1984; Conovan 1961; and Willhoite 1963). Others have developed more elaborate hierarchies.

As suggested by Bernard Cohen's observation quoted above, however, beyond these very general observations there is very little consensus about consensus. With a few exceptions, there has been a rather limited dialogue between political theorists, whose concerns tend to focus on macro-level questions, and students of public opinion, who undertake micro-level analyses. Even among the latter, whose studies are usually empirical and quantitative, there has been relatively limited attention addressed to the levels of agreement necessary to constitute a consensus. In his classic study, Public Opinion and American Democracy, V.O. Key (1961) devotes an entire chapter to consensus; yet, although the book is heavily dependent on survey data, nowhere does he identify the threshold for consensus. Indeed, it is not unusual to find an article or even an entire book on consensus in foreign policy that does not even attempt to define the term, much less state what proportion of the population must support a policy in order to constitute a consensus (e.g., Chase 1978; Holsti and Rosenau 1984). A lack of precision about the meaning of consensus is not limited to scholarly analyses, and fuzziness on that score sometimes may be functional. A recent summary of multiparty talks in South Africa points out that on a central issue, "The deadlock-breaking mechanism agreed on at the Convention for a Democratic South African last year was the imprecise concept of 'sufficient consensus.' What level of consensus is that?" (Economist 1993, 43). Whether that imprecision will come back to haunt the negotiators remains to be seen.

There are some exceptions to these observations, however, as a few analysts have ventured to establish precise operational definitions of consensus. Prothro and Grigg (1960) proposed a demanding criterion of consensus wherein agreement on any proposition must reach 90 per cent. ${ }^{2} \mathrm{Al}-$ though this study is widely cited as a pioneering empirical effort that uses survey data to identify areas of consensus among the American public, other analysts who actually cite a specific threshold usually adopt a somewhat less demanding criterion.

.. . we shall take as a minimal requirement for consensus a level of agreement reaching 75 percent. This figure, while also arbitrary, recommends itself to being 
realistically modest (falling as it does midway between a bare majority and unanimity), and by having been designated in this country and elsewhere as the extraordinary majority required for certain constitutional purposes (McClosky 1964, 363). ${ }^{3}$

... ratification [of treaties] requires a two-thirds vote. This is the main reason for defining an attitude consensus at the approximate level of two-thirds (Graham 1989, 57).

A broad agreement which, while not necessarily all-embracing, does embrace enough elements to form a sizable majority ... In the American political tradition, a very big majority is taken to lie somewhere between 60 percent and 75 percent. An American consensus is more than a bare 51 percent (Safire 1978).

Majority support —an admittedly timid criterion for consensus — was typically (but not universally) realized before Vietnam ... (Wittkopf 1990, 192).

This brief sample of operational definitions illustrates the absence of agreement on the threshold for consensus.

This paper makes another effort at an operational definition of consensus. Although the undertaking is motivated by some dissatisfaction with existing definitions, it also attempts to draw upon aspects of earlier studies in order to avoid mindless reinvention of the wheel. Several premises inform this effort.

1. It is useful to disaggregate the concept of consensus rather than to think about it as a condition that can adequately describe all aspects of public policy at any one time. Presumably even during the most harmonious periods - for example, during the so-called "era of good feeling" of the early nineteenth century - there must have existed important issues that, had we access to adequate survey data, would have revealed sharp divisions among the public and/or opinion leaders. Conversely, even as the nation was about to split apart on the eve of the Civil War, there must have been some issues that would have elicited a high level of agreement on both sides of the Mason-Dixon Line. ${ }^{4}$

2. It is useful to establish a hierarchy of subjects about which people can agree or disagree. Because the specific interests that gave rise to this effort focus largely on the foreign policy views of American opinion leaders, examples and evidence used throughout this paper are drawn from the Foreign Policy Leadership Project surveys of American opinion leaders in 1976, 1980, 1984, and 1988. ${ }^{5}$ For illustrative purposes, a distinction is drawn between several clusters of items ranging from general and philosophical beliefs about world affairs to assessments of specific foreign policy undertakings: 
- Basic philosophical beliefs about foreign affairs:

- The causes of war

-Approaches to peace

- The U.S. in world affairs:

- The goals of American foreign policy

- U.S. roles and interests

- The international environment:

- The nature of the international system

- The nature of key actors, including adversaries

- Foreign policy-making processes

- Means and instruments of foreign affairs

- Specific policies and undertakings

3. It is more useful to develop a scheme that permits identification of several levels of consensus than to conceive of consensus as a dichotomous variable. Those described below distinguish between three levels of consensus [strong, moderate, and weak], as well as three levels of dissensus.

4. A definition of consensus should require something more than a majority and less than unanimity. If unanimity is necessary, then the concept will be applicable only for describing views within small groups such as cabinets, advisory groups, and the like, and it will have no utility in survey research or voting studies, even in authoritarian states. On the other hand, if a bare majority is sufficient to establish a consensus, then the concept is redundant.

As a starting point, thresholds of 75 percent and 25 percent will be used to identify the strongest levels of consensus. Thus, when opinion on a proposition equals or exceeds 75 percent-or, conversely, when it falls below 25 percent - it will be deemed to have met one important criterion for establishing a strong consensus.

5. The distribution of opinions within groups can be as important as the distribution throughout the entire sample of respondents. For U.S. public policy issues, political parties are often, but not always, the most important groups. A simple example illustrates how between-group differences may be significant. Consider the distribution of responses on two issues. Issue A finds both Democrats and Republicans divided 2-1, or 67 percent, in favor. In this case, we have what V.O. Key $(1961,37)$ called a "concurrent consensus." Issue $\mathrm{B}$, on the other hand, gives rise to unanimous agreement among Democrats but it finds favor among only 33 percent of Republicans. Assuming that the sample includes approximately equal numbers of adherents to the two major parties, both issues result in identical (67 percent) aggregate levels of agreement. There is reason to suspect, however, that the 
policy processes - and perhaps even outcomes - may be different on the two issues. For this reason, the scheme described below takes into account the distribution of responses in two groups. For illustrative purposes the groups are Democrats and Republicans, but other groups - for example, those defined by ideology, gender, military service, etc.- -also could be used.

The schemes in the next section deal with four types of response options, the first two of which do not take intensity of opinions into account: percent "agree," and percent "very important." The second pair of schemes is designed for more complex response options with a two-sided scale ("agree strongly," "agree somewhat," "no opinion," "disagree somewhat," and "disagree strongly") and a single-sided scale ("very important," "somewhat important," and "not important at all").

\section{A Scheme for Measuring the Level of Consensus}

Table 1 depicts the basic structure of the proposed approach for measuring the degree of consensus in a two-party system. ${ }^{6}$ It may be used for any questions on which respondents are given only two substantive response options with opposite valences (agree-disagree, support-oppose, yes-no, etc.). It arbitrarily divides aggregate responses of Republicans and Democrats into quartiles, thereby creating a $4 \times 4$ matrix. The highest level of consensus occurs when respondents of each party register either at least 75 percent agreement on any item (cell D) or less than 25 percent agreement (cell M). Conversely, the highest level of dissensus occurs when respondents of one party record at least 75 percent agreement whereas fewer than 25 percent of those in the other party agree (cells A and P). In addition to these cases of maximum consensus and dissensus, the scheme also permits four additional outcomes, two of which describe lower levels of consensuslabeled here as "moderate bipartisan consensus" (cells C, H, I, and N) and "weak bipartisan consensus" (cells G and J) - as well as two additional levels of dissensus: "dissensus within and between parties" (cells F and K), and "partisan dissensus" (cells B, E, L, and O).

However, not all survey items offer response options with a valence (agree-disagree, etc.). Respondents may be asked to assess the importance of goals or to rate causal factors (for example, the causes of war, approaches to peace) along a scale ranging from "very important" to "not important at all." The scheme outlined above readily can be adapted to such questions. Specifically, we could assess the degree of consensus by recording the percentages of Democrats and Republicans who rate a foreign policy goal as "very important." Once again, a "strong bipartisan consensus" 
Table 1. Consensus and Dissensus in a Two-Party System Based on Percentage of Agreement

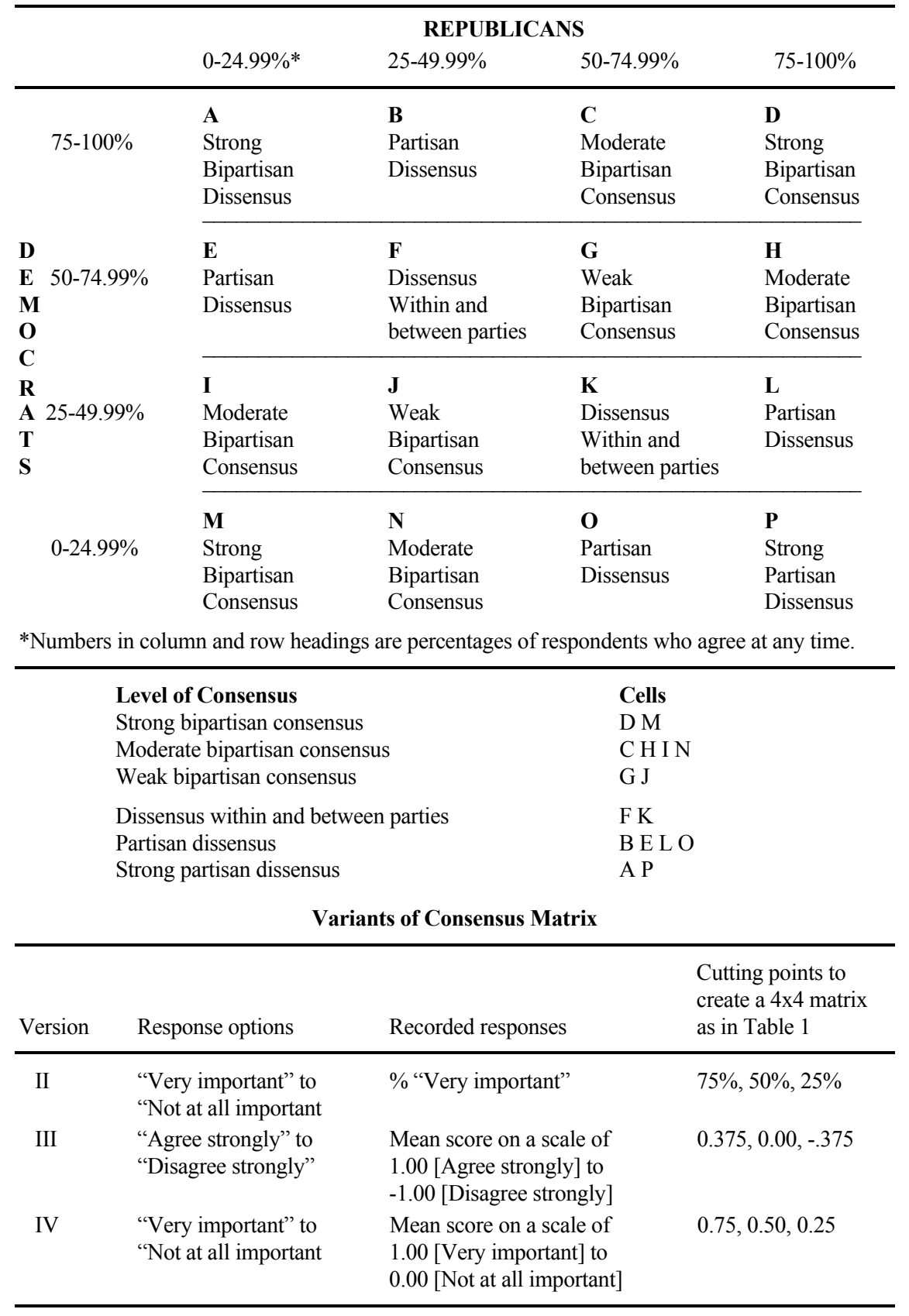


would result when more than 75 percent or fewer than 25 percent of both Republicans and Democrats accord the highest importance rating to a foreign policy goal, as in Table 1, version II (see Table 1 legend, "Variants of Consensus Matrix").

\section{Taking Intensity of Opinion into Account}

The scheme described in Table 1 does not make full use of the data when survey participants are given more than two response options; for example, when they have an opportunity to express the intensity of their judgments. As is often the case when respondents are asked to agree or disagree with a statement, the actual response options on many questions in the FPLP surveys have been: "Agree strongly," "agree somewhat," "disagree strongly," "disagree somewhat," and "not sure." Table 1 lumps together the first two of these options to determine the percentage of agreement and disregards the rest of the data. Similarly, by recording only the "very important" ratings, Version II disregards the distinction between assessing goals as "somewhat important" and as "not important at all."

These problems easily can be overcome. Response options ranging from "agree strongly" to "disagree strongly" can be transformed into a scale of 1.00 to -1.00 by scoring "agree strongly" as 1.00 , "agree somewhat" as 0.50 , "not sure" as 0.00 , "disagree somewhat" as -0.50 , and "disagree strongly" as -1.00 . Responses by Democrats and Republicans then can be divided into a four point scale, again yielding a $4 \times 4$ matrix, with cutting points at $0.375,0.00$, and -0.375 , as in Table 1 , Version III (see Table 1 legend). A similar transformation permits the full use of responses to items that offer respondents more than two options in assessing importance. A scale of 0.00 to 1.00 is created by scoring "very important" responses as 1.00 , "somewhat important" as 0.50 , and "not important at all" as $0.00{ }^{7}$ By dividing the resulting scale into quartiles, with cutting points at $0.75,0.50$ and 0.25 , Version IV maintains the $4 \times 4$ format and cell labels of Table 1.

The remainder of this paper uses Versions III and IV of Table 1 because they permit the fullest use of the data by taking into account the intensity of responses. The data, drawn from the 1976-1988 Foreign Policy Leadership Project surveys, are organized according to the hierarchy described above, starting with general philosophical beliefs about international affairs - the causes of war and approaches to peace - and proceeding toward appraisals of specific American foreign policies and undertakings during the period approximately corresponding to the second Reagan Administration. 


\section{The Causes of War and Approaches to Peace}

Two clusters of items in the 1984 and 1988 questionnaires focus on the central questions of international relations: the causes of war and approaches to peace. Responses to a series of questions on the former issue reveal relatively few partisan differences (Table 2). A strong bipartisan consensus locates the most important causes of war in the actions of aggressive nations and of specific leaders such as Hitler and Stalin. These findings are consistent with Waltz' (1959) observation that Americans tend to favor "image one" (individual traits, including those of leaders) and "image two" (aggressive nations) explanations for war, while more often overlooking "image three" theories that place emphasis on the context of international relations (a self-help system that cannot prevent war). Indeed, adherents of both parties are divided on the proposition that war arises from an anarchical international system that lacks a central authority to settle disputes, and opinion leaders of both parties rate this as the least potent explanation for war. It also is noteworthy that, although the 1984-1988 period was marked by significant international change, especially in the tenor of superpower relations, assessments of the causes of war remained very stable, not only in the aggregate but also among both Republicans and Democrats. These results indicate that at the most general level there is a rather broad consensus among American opinion leaders.

A parallel cluster of items asked respondents to assess several approaches to peace (Table 3). The results also reveal a good deal of stability in responses over the 1984-1988 period, as well as a somewhat lower level of consensus than on the causes of war. A moderate bipartisan consensus endorsed some of the central prescriptions of "realist" theoriesmilitary superiority and collective security - despite a wide gap between Republicans and Democrats on the efficacy of the former approach. Balance-of-power politics and arms control, two other military/strategic prescriptions, resulted in lower levels of agreement. The prescriptions often favored by liberal internationalists also elicited a mixed pattern of responses. A moderate consensus rated trade and better international communications as effective approaches to peace, but agreement did extend to prescriptions that emphasize an enhanced role for international organizations or narrowing the gap between rich and poor nations. Although more Democrats than Republicans ascribed importance to the latter two prescriptions, even they did not rate them among the most important approaches to peace. 


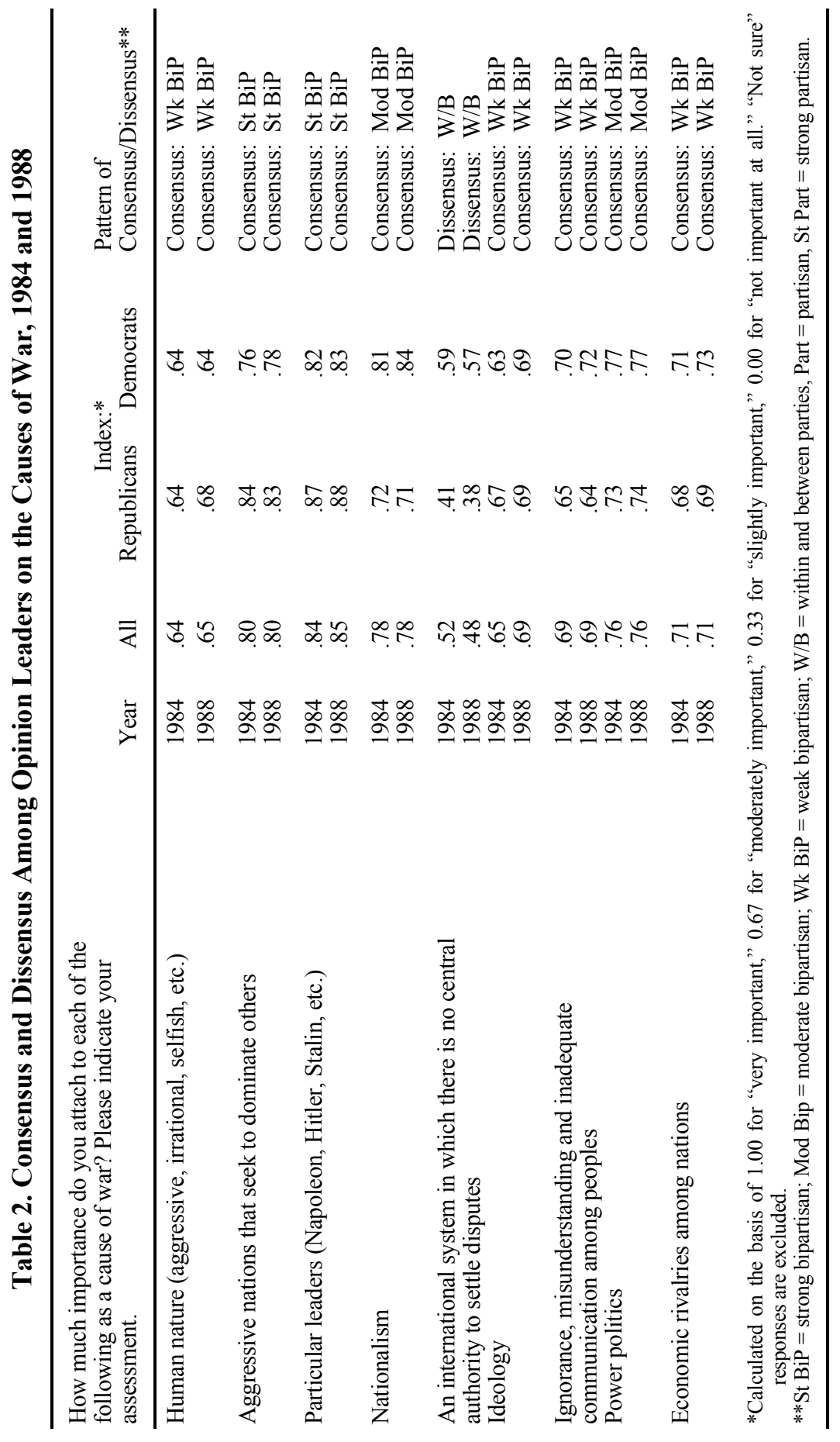




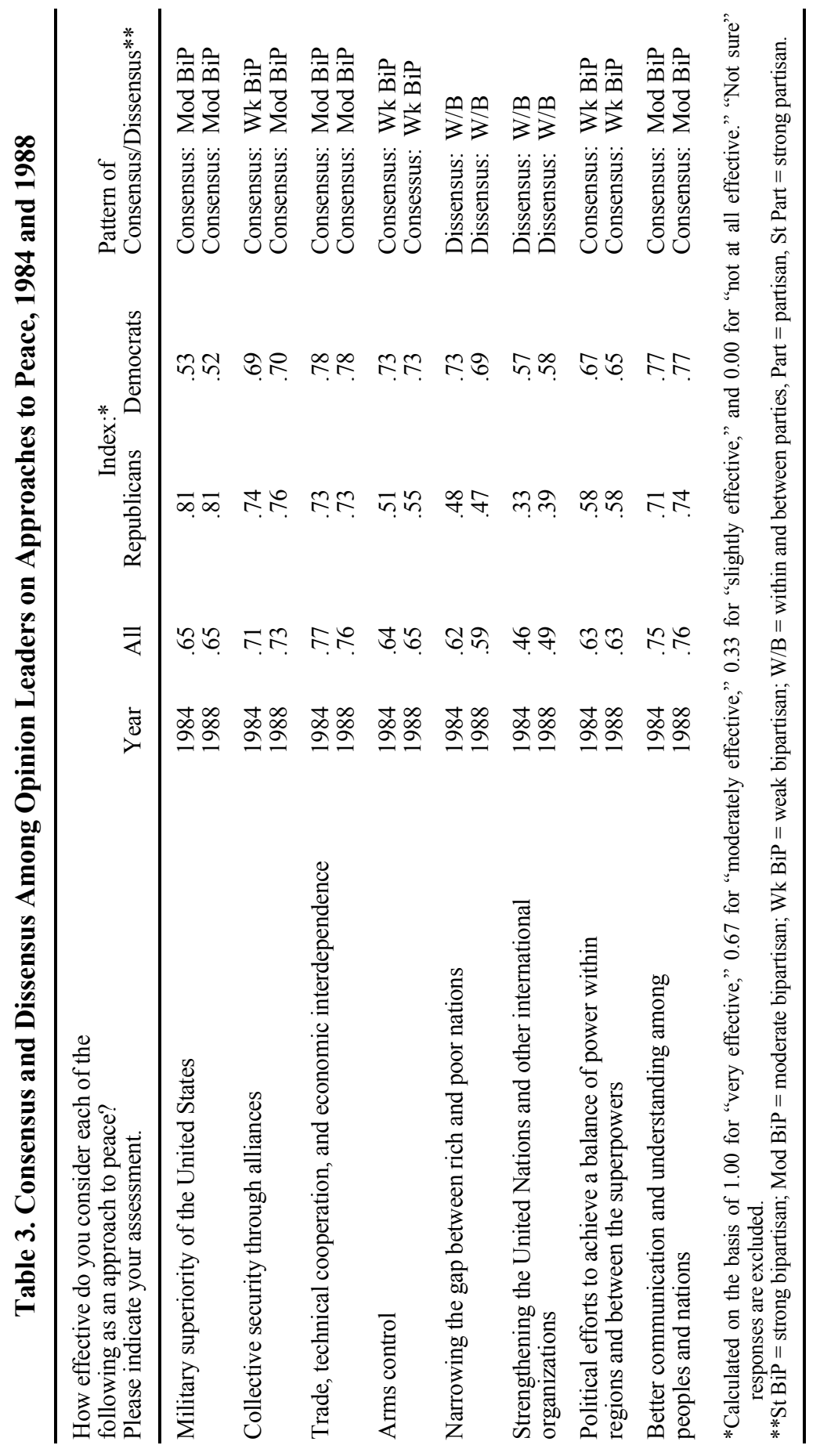




\section{The United States in World Affairs}

The next two tables present some illustrative data on U.S. foreign policy roles and interests and foreign policy goals. The evidence in Table 4 reveals moderate levels of consensus in support of the proposition that the United States has broad international interests and opposed to a general isolationist stance toward world affairs. Differences both within and between parties, however, characterized responses to the statement that, "The best way to encourage democratic development in the "Third World' is for the U.S. to solve its own problems." Most notably, the opinion leaders taking part in the four surveys consistently and with increasing vehemence have rejected the proposition that "It is not in our interest to have better relations with the Soviet Union because we are getting less than we are giving to them." While rejecting a general isolationism, members of both parties were divided on whether the U.S. should scale down its leadership role and whether, in any case, economic profligacy would bring that role to an end.

The data on the importance of foreign policy goals reported in Table 5 include intensity of responses, with scores ranging from 1.00 (all "very important" ratings) to 0.00 (all "not important at all" judgments). The evidence reveals that by 1988 there was a strong bipartisan consensus on the importance of several international economic goals, including access to adequate energy supplies, international economic cooperation, and coping with the trade deficit, while there was a moderate consensus on dealing with Third World debts, hunger, and the environment. In contrast to the economic issues, those with a Cold War tenor elicited mixed results. The moderate level of consensus that had persisted through 1984 on the goals of containment and matching Soviet military power had evaporated in 1988, but there also was increasing agreement on the importance of defending the security of allies. The goal of strengthening the United Nations gave rise to the deepest and most persistent disagreement between Republicans and Democrats.

\section{The Global Environment}

Table 6 reports responses to six questions about the international system. A strong bipartisan consensus rejected the proposition that Third World conflicts are irrelevant to American interests, while the partisan dissensus of 1976 has given way to a moderate consensus that Third World revolutionaries usually act from nationalist motives rather than as pawns of the Soviet Union or China. The most divisive issues include two central Cold War propositions about the validity of the "domino theory" and a zero- 


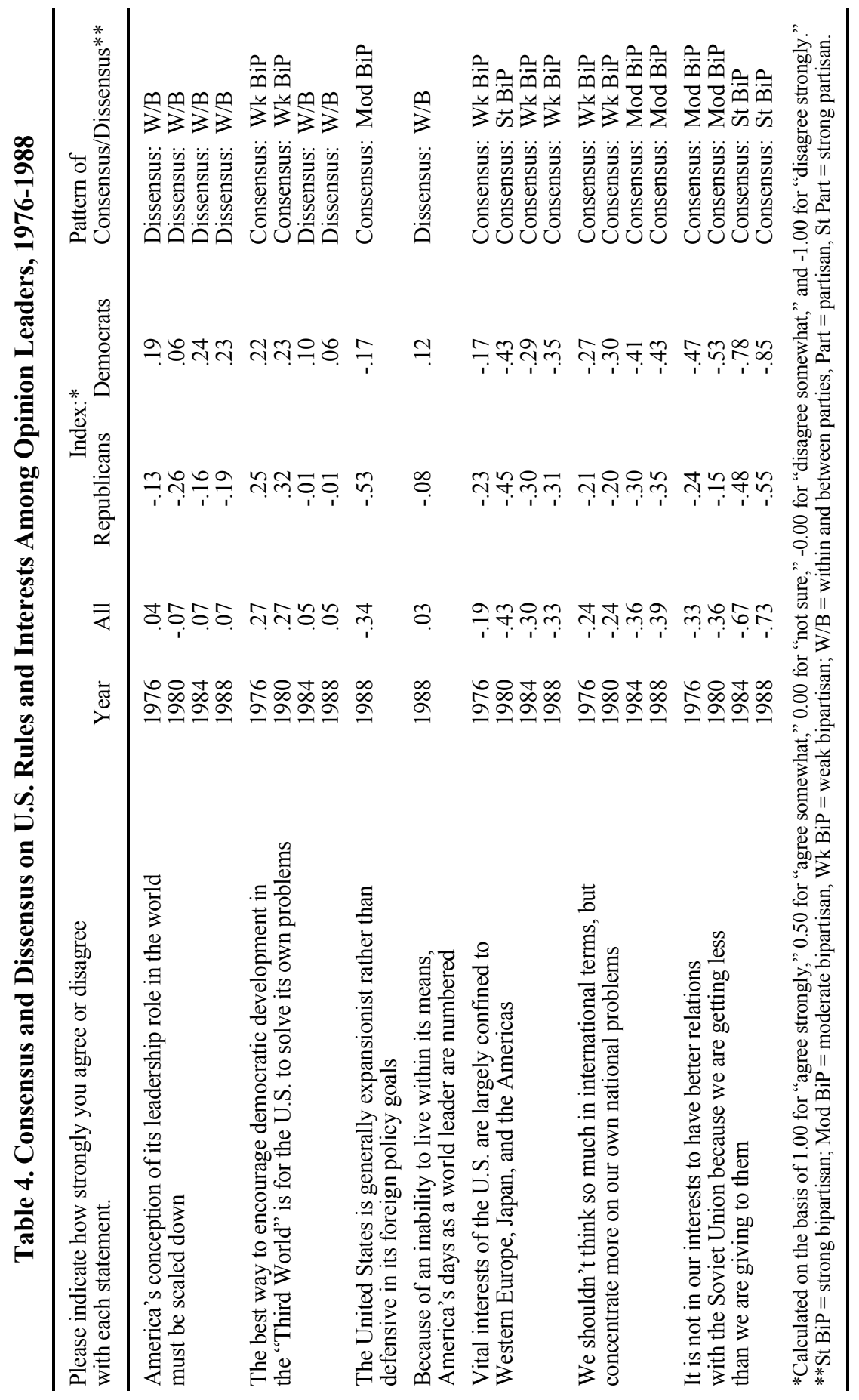




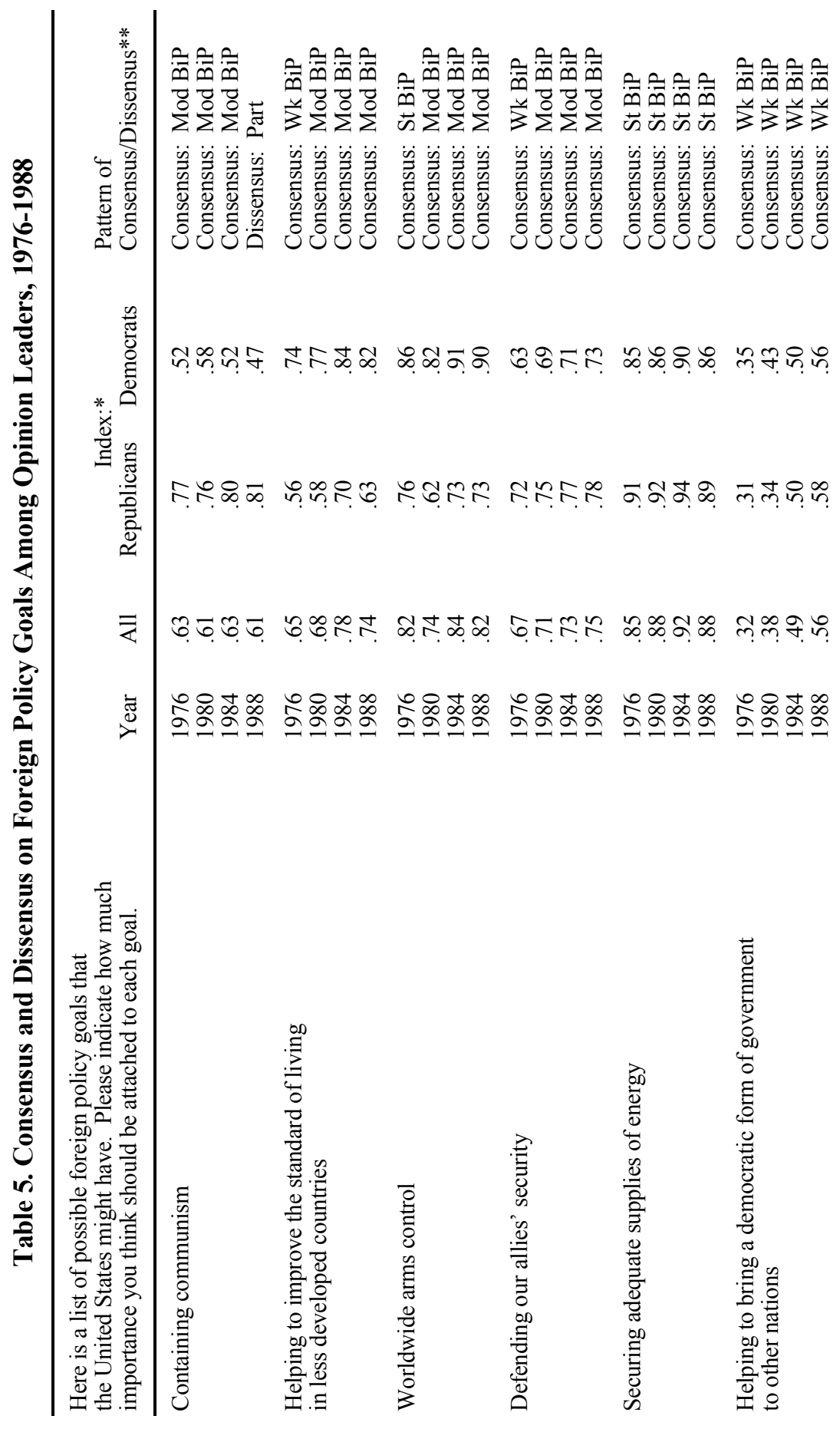




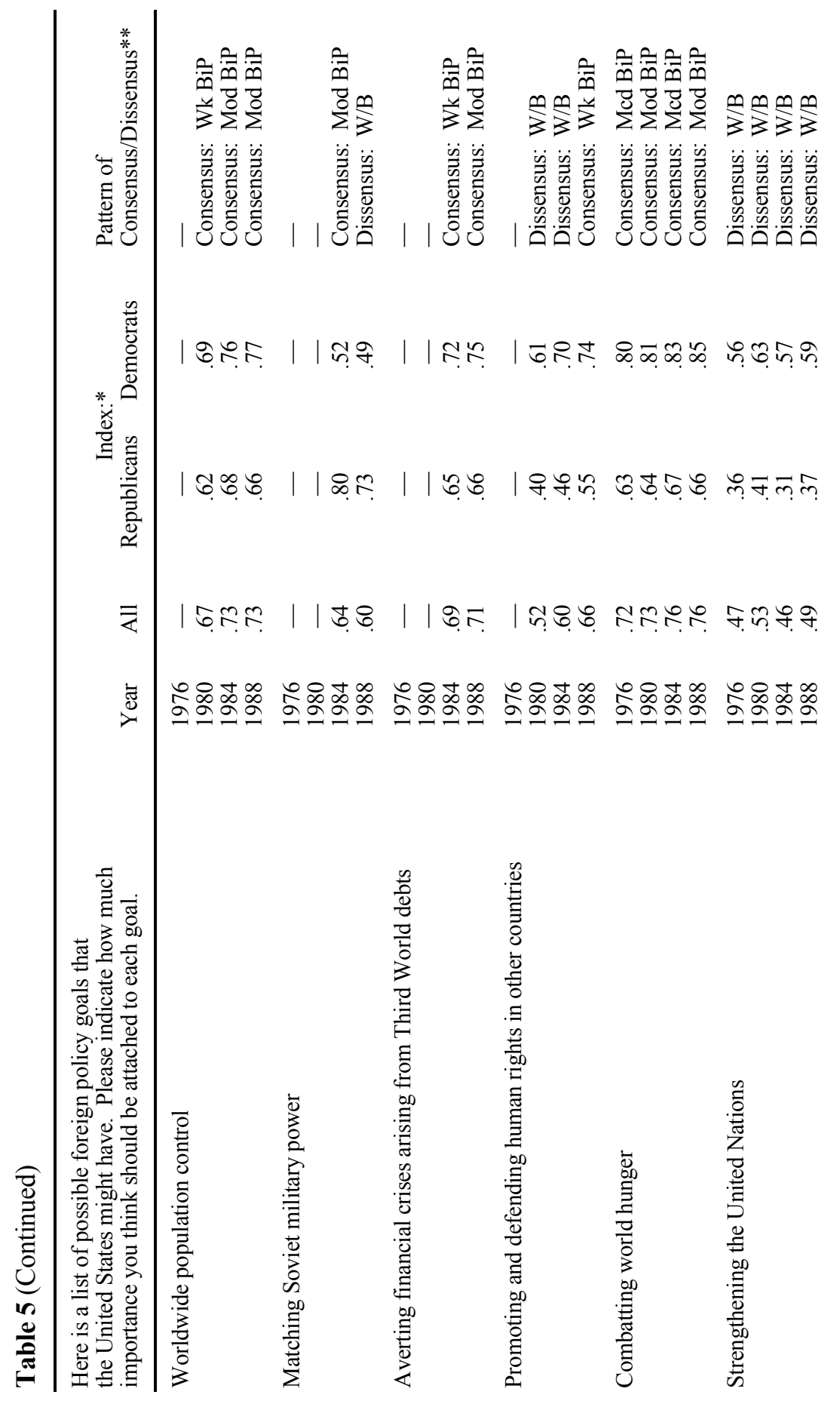


Toward an Operational Definition of Consensus | 323

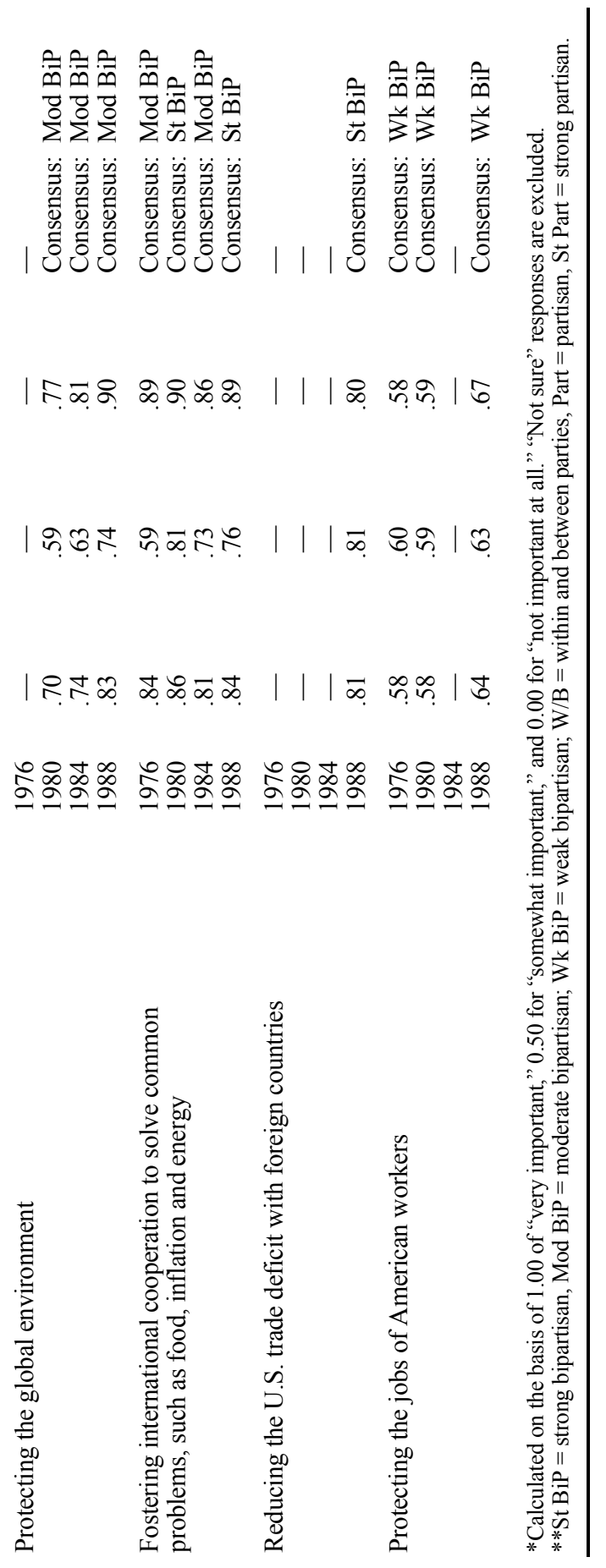




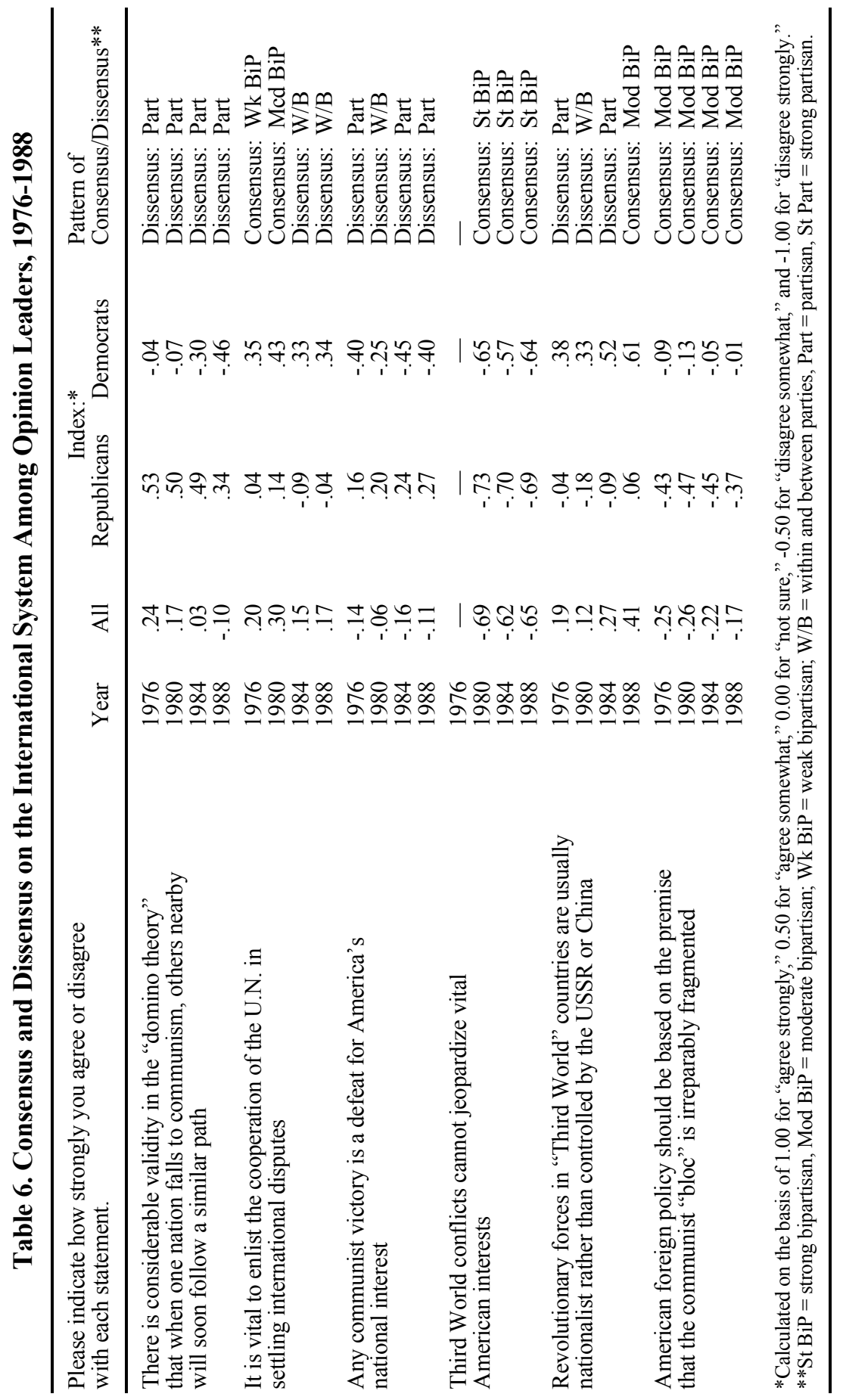


sum view of the international system. Although Democrats were more optimistic about the utility of the United Nations in dealing with international conflict, there also were differences within both parties on the issue.

Each of the FPLP surveys included several items that deal with America's traditional Cold War rivals, China and the Soviet Union. Responses are summarized in Table 7. By 1976, four years after President Nixon's first trip to China, a consensus - albeit a weak one - had rejected the proposition that the Beijing government was expansionist rather than defensive in its foreign policy. The subsequent three surveys over the next twelve years revealed a trend among both Democrats and Republicans toward the more benign interpretation of China's international behavior.

Responses to the larger cluster of questions on the USSR also reveal a trend toward a softening interpretation of some, but not all aspects of the Kremlin's policies. By 1988 there were varying levels of consensus on the propositions that: the Soviets are risk averse in foreign affairs; the superpowers share a number of major interests; the USSR, while generally expansionist in its foreign policy, often acts out of genuine concerns for its own security; and President Gorbachev sincerely seeks better relations with the United States. On the other hand, partisan disagreement characterized responses on a number of other issues, including the propositions that: the Soviets have abused detente, expansionist motives lay behind the invasion of Afghanistan, the Kremlin's foreign policy goals resemble those of a typical great power, and a fundamental transformation of the Soviet system is a necessary condition for moderating its approach to foreign affairs. In each case of partisan dissensus, Democrats adhered to a more benign interpretation of the Soviet Union.

\section{Foreign Policy Processes}

Responses to several items dealing with the foreign policy-making process are reported in Table 8. The twelve-year period of the FPLP surveys had been dominated by divided government (except during 1977-1980, when the Democrats controlled the White House and both houses of Congress) and often acrimonious relations between these two branches of government. Thus, it is hardly surprising that a consistent bipartisan consensus emerged on the proposition that "An effective foreign policy is impossible when the Executive and Congress are unable to cooperate." Beyond agreement on that point, dissensus is more evident than consensus. Democrats consistently have supported the view that the press is more truthful than the government about foreign affairs, even in the 1980 survey when, as indicated above, members of their party controlled both the White 


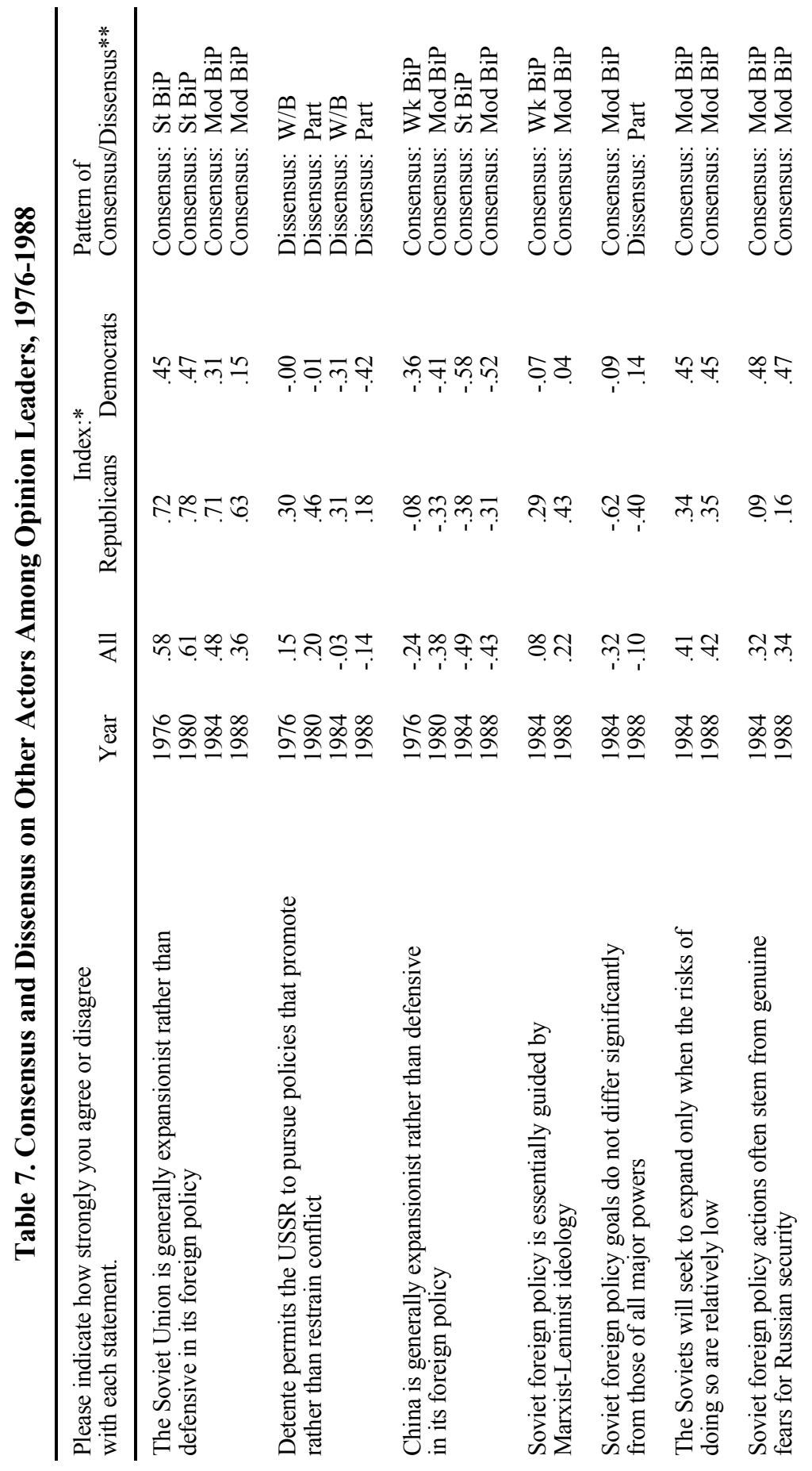


Toward an Operational Definition of Consensus | 327

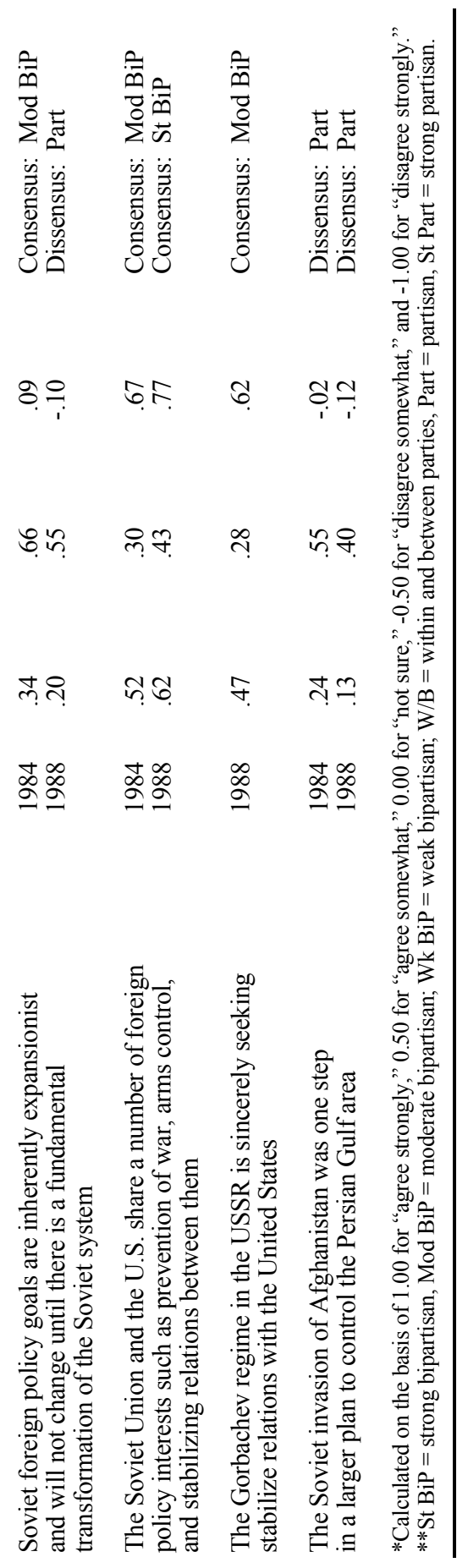




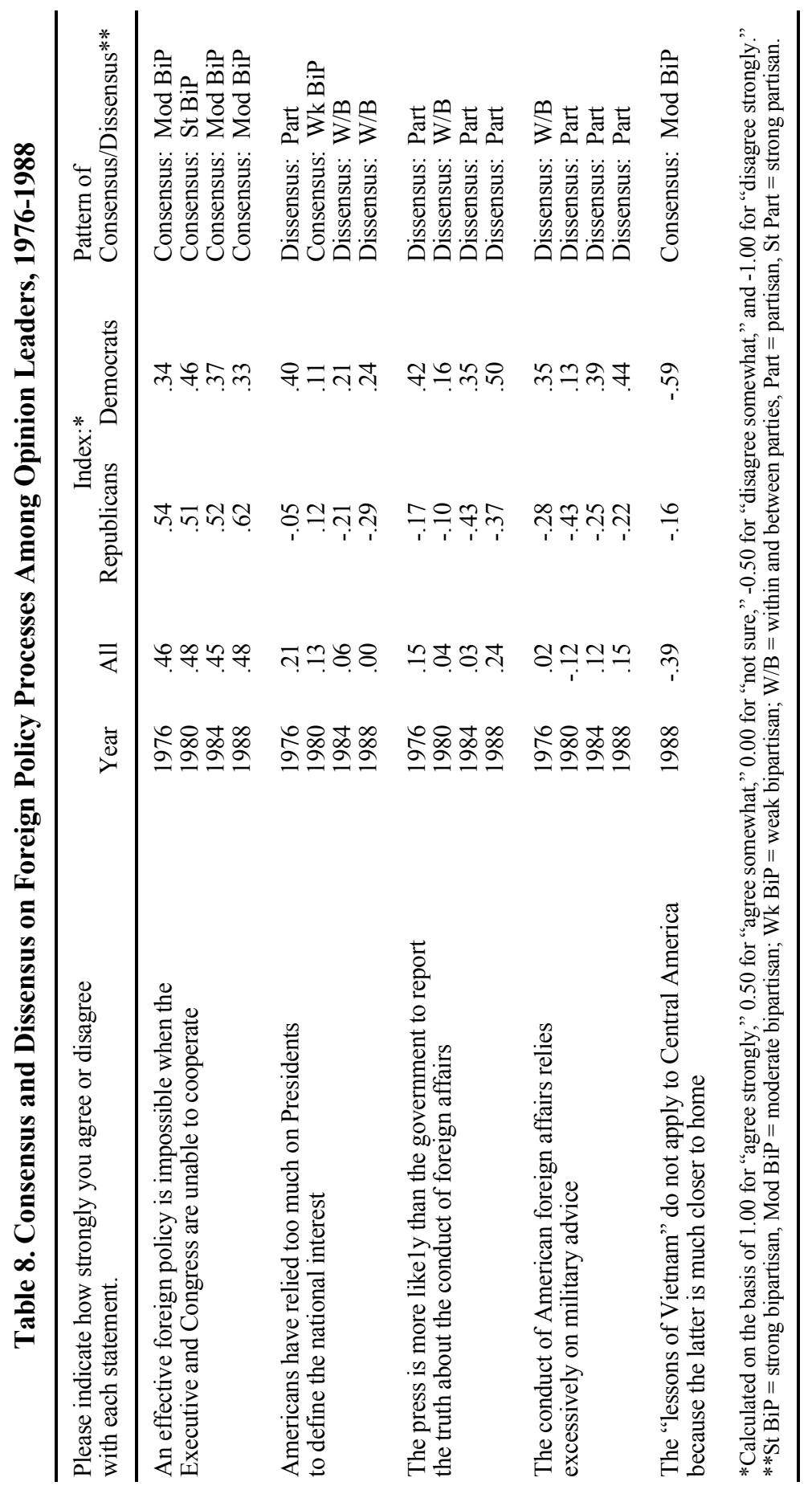


House and the Congress. Republicans, on balance, consistently have held the opposing viewpoint. Partisan dissensus also has dominated responses to questions on the roles of military advice and of the President, respectively, in defining the national interest.

\section{Means and Instruments of Foreign Policy}

Questions on the means and instruments of foreign policy reveal several areas of strong disagreement. None of the ten items in Table 9 gave rise to a strong bipartisan consensus, and only three items - those concerning domestic political constraints on conducting limited wars, opposition to graduated escalation, and opposition to letting military goals dominate political goals when force is used-resulted in even a moderate level of consensus. Conversely, partisan dissensus emerged on the consequences of military aid programs, the uses of the CIA against hostile governments, and taking all necessary steps to prevent the spread of communism.

\section{Foreign Policy Undertakings}

The hypothesis that specific policies and decisions are likely to engender greater disagreement than more fundamental questions about constitutions and procedures dominates much of the literature on consensus. The results reported in Table 10, focusing on sixteen American foreign undertakings of the period immediately preceding the 1988 FPLP survey, are consistent with that hypothesis. Only the American-Soviet agreement to eliminate intermediate-range nuclear forces (INF Treaty) and American efforts to replace the Marcos government in the Philippines elicited sufficient support from both Democrats and Republicans to meet the requirements for a strong bipartisan consensus. Covert arms sales to Iran also evoked strong bipartisan opposition. More moderate agreement emerged on disapproval of the Iran-contra affair, opposition to protectionism, and approval of arms sales to Saudi Arabia.

On the other hand, the Reagan Administration's policies of aid to the Contras in Nicaragua and to the government in El Salvador created strong partisan dissensus, as did its strong stand on the Strategic Defense Initiative. Partisan differences also emerged on a number of other major foreign policy undertakings, including the defense buildup, the failure to adhere to the War Powers Act in connection with the reflagging of Kuwaiti oil tankers operating in the Persian Gulf, assistance to rebels in Angola, a bombing raid on Libya, additional funding for the International Monetary Fund, and the imposition of economic sanctions on South Africa because of its policy of 


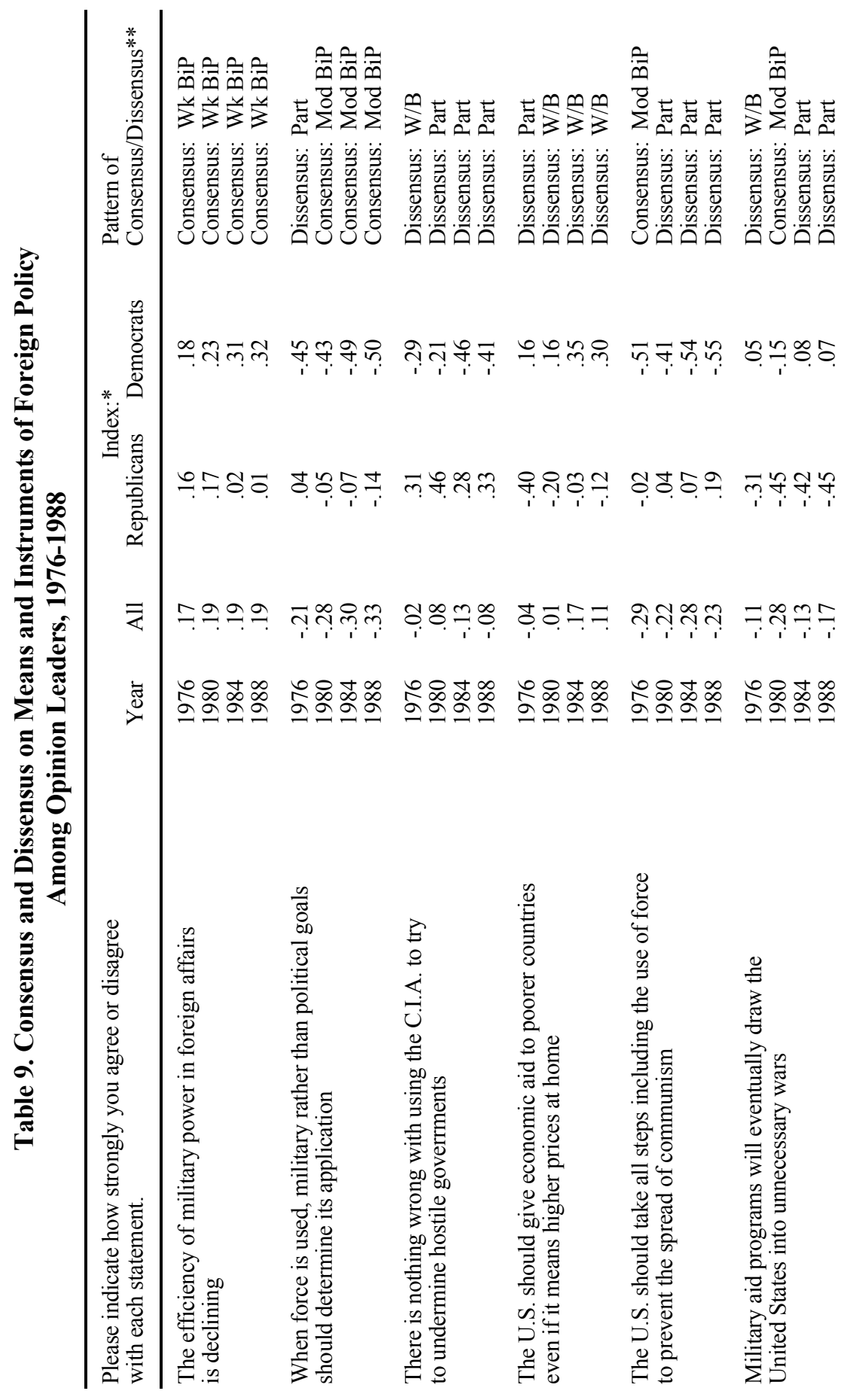




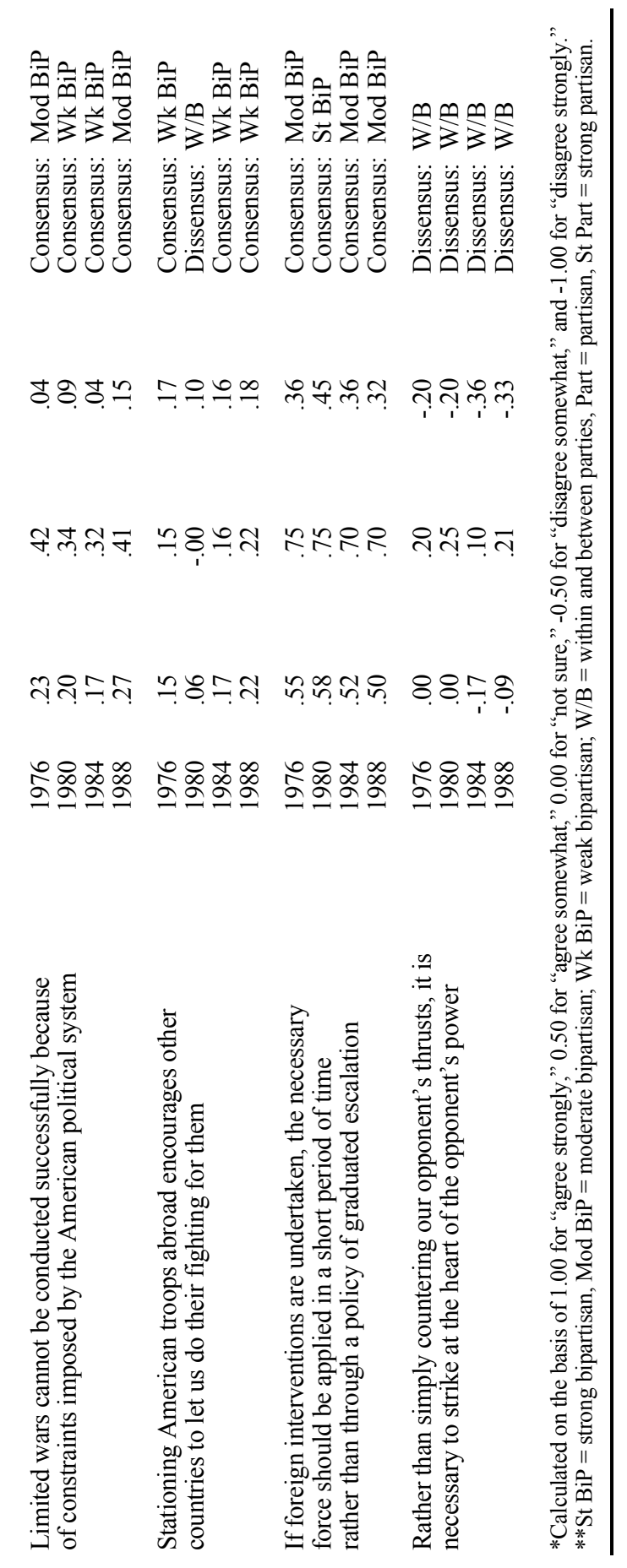




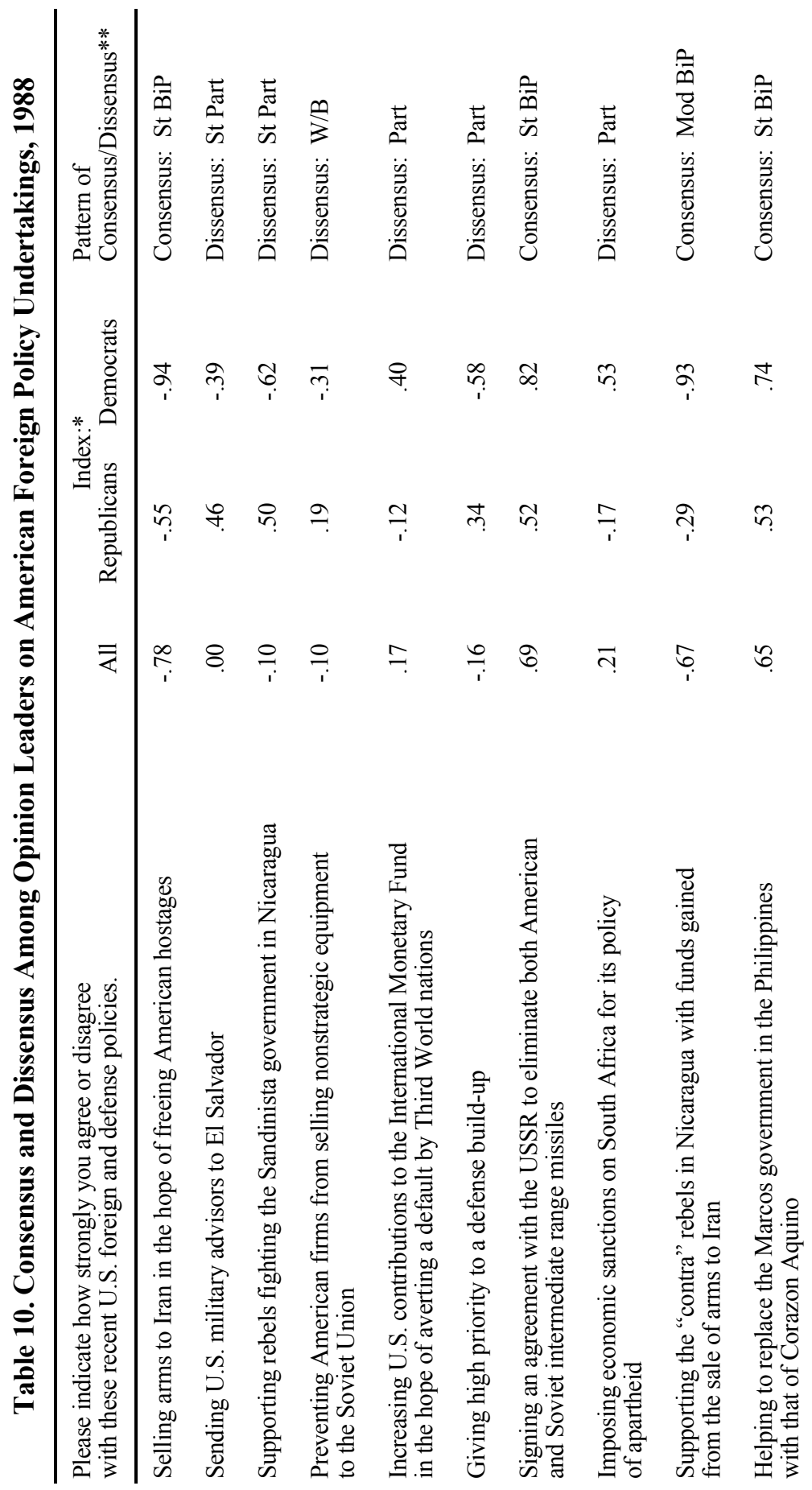


Toward an Operational Definition of Consensus | 333

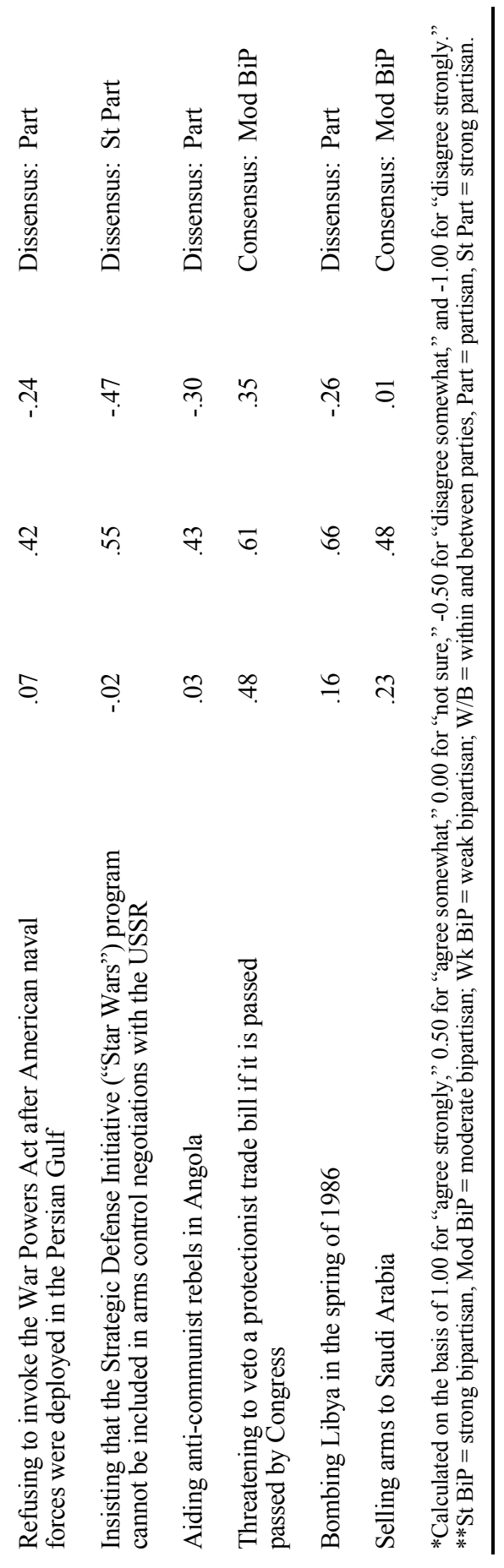


apartheid. The latter two undertakings, only grudgingly accepted by the Reagan Administration, garnered greater support among Democrats than Republicans.

\section{Discussion}

This paper has developed and illustrated a scheme for assessing the level of consensus with survey data. Four versions of the scheme were presented in Table 1 in order to deal with some of the more widely used response options, including those that permit respondents to express the intensity of their opinions. The data in Tables 2-10 are intended to illustrate the possibilities - and perhaps to assist in identifying weaknesses of the scheme-rather than to present a full scale substantive analysis of the 19761988 FPLP surveys.

The results of analyses such as these may be used for a variety of purposes, including assessment of trends and of the structure of consensus and dissensus at a given time. Table 11, based solely on the 1988 survey data found in Tables 2-10, summarizes the results using the hierarchy discussed earlier. On the whole, the findings appear to provide considerable support for the premises that it is useful to disaggregate the concept of consensus and to think in terms of a hierarchy of topics. In brief, the 1988 survey data indicate that American opinion leaders could be described as enjoying a foreign policy consensus on a substantial number of propositions at rather general levels (diagnoses of the causes of war, prescriptions regarding approaches to peace, goals for American foreign policy). However, in contrast to the broad agreement on economic goals, questions with a strategic/military/Cold War tenor often gave partisan dissensus. Stated differently, much of the evidence pointed toward a continued erosion of the broad agreement that supported U.S. foreign and defense policies during the first two decades of the Cold War. At the same time, there are many areas of considerable dissensus on the more specific aspects of foreign relations, including policy-making processes, means and instruments used in the conduct of foreign affairs, and specific policies and undertakings.

The scheme also can help to identify trends in partisanship/bipartisanship that might not be apparent from an inspection of aggregate results. For example, although overall ratings on the importance of "containing communism" as a foreign policy goal remained relatively stable over the 19761988 period, the figures in Table 5 indicate that ratings among Republicans and Democrats were moving in the opposite direction. What had been a moderately strong bipartisan consensus was transformed into partisan dissensus. The same pattern may be discerned with respect to another Cold 
Table 11. Consensus and Dissensus in the 1988 Foreign Policy Leadership Survey

\begin{tabular}{|c|c|c|c|c|c|c|}
\hline \multirow[b]{2}{*}{ Subject [Table] } & \multicolumn{3}{|c|}{ Consensus } & \multicolumn{3}{|c|}{ Dissensus } \\
\hline & Strong & Moderate & Weak & $\begin{array}{l}\text { Within/ } \\
\text { Between }\end{array}$ & Partisan & $\begin{array}{c}\text { Strong } \\
\text { Partisan }\end{array}$ \\
\hline \multicolumn{7}{|l|}{ General/philosophical } \\
\hline Causes of war [2] & 2 & 2 & 4 & 1 & 0 & 0 \\
\hline Approaches to peace [3] & 0 & 4 & 2 & 2 & 0 & 0 \\
\hline \multicolumn{7}{|l|}{ The U.S. in world affairs } \\
\hline Roles and interests [4] & 1 & 2 & 1 & 3 & 0 & 0 \\
\hline Goals of U.S. policy [5] & 3 & 7 & 3 & 2 & 1 & 0 \\
\hline \multicolumn{7}{|l|}{ The global environment } \\
\hline International system [6] & 1 & 2 & 0 & 1 & 2 & 0 \\
\hline Adversaries [7] & 1 & 6 & 0 & 0 & 4 & 0 \\
\hline Foreign policy processes [8] & 0 & 2 & 0 & 1 & 2 & 0 \\
\hline Means and instruments [9] & 0 & 3 & 2 & 2 & 3 & 0 \\
\hline Specific policies [10] & 3 & 3 & 0 & 1 & 6 & 3 \\
\hline
\end{tabular}

War policy maxim, "The U.S. should take all steps including the use of force to prevent the spread of communism" (Table 9). On balance, the leadership samples in all four surveys expressed more disagreement than agreement, with little change across time, and the responses of Democrats varied only slightly during the twelve year period in question. But there were sufficient changes among Republicans, toward greater agreement with the proposition, to transform a moderate bipartisan consensus into partisan dissensus.

From a different perspective, could one achieve the same goals by using somewhat more conventional methods-for example, by reporting the overall level of agreement on each item as well as the statistical significance of differences in responses by Democrats and Republicans? While the different modes of analysis often would yield essentially similar results, that is not invariably the case. For example, in response to an item in the 1988 FPLP survey-"The Senate should ratify the INF Treaty without changes"78 percent of the Republicans and 85 percent of the Democrats agreed. The seven percent gap in their support for the INF Treaty is statistically significant at the .001 level. According to the proposed method of analysis, however, whether or not the intensity of agreement is taken into account, this distribution of responses is recorded as indicating a "strong bipartisan 
consensus" because both Republicans and Democrats exceeded the required levels of agreement. Moreover, overall levels of agreement with any item actually may conceal quite different patterns of partisan responses. As the overall level of agreement approaches 50 percent, the variety of possible patterns of consensus or dissensus increases.

It also is important to identify the limitations of this scheme. Because it is intended to summarize the data item by item, it is at best a rather clumsy tool for describing belief structures or hierarchies, an undertaking that focuses on relationships across items. To be sure, items that give rise to very strong partisan differences may offer some clues about beliefs that are likely to cluster together, but there are far better and more direct ways of ascertaining whether such patterns exist; for example, by computing correlations, creating scales, or undertaking factor analyses. ${ }^{8}$

Several objections may be raised about the schemes developed here. The most obvious one concerns the location and even the number of cutting points used to develop the matrix (and its three variants) in Table 1. Although consistent with the authors cited, who argue for 75 percent as an important threshold for achievement of a consensus, this scheme certainly is not immune from the criticism that the cutting points have been set at an unrealistically high level. ${ }^{9}$ If 75 percent is deemed to be an overly demanding criterion for the highest level of consensus, the cutting points easily could be changed. For example, if a two-thirds majority is preferable to three-fourths, then the column and row designations would be as follows:

Table 1, Version II: 0.0 to 33.3 percent; 33.3 to 50.0 percent; 50.0 to 66.7 percent; and 66.7 to 100 percent.

Version III: 0.25 to $1.00 ; 0.00$ to $0.25 ;-0.25$ to 0.00 ; and -1.00 to -0.25 .

Version IV: 0.00 to $0.33 ; 0.33$ to $0.50 ; 0.50$ to 0.67 ; and 0.67 to 1.00 .

The resulting tables still would include sixteen cells with the same labels. If these cutting points were used, it would tend to push results away from the center of the matrices and toward the corner cells. It would be tedious, to say the least, to reproduce all of the data in Tables 2-10 using the different cutting points, but the tendency toward more frequent use of the corner cell can be illustrated by redoing the summary results for the 1988 survey reported in Table 11. As indicated in Table 12, the pattern of responses results in an approximate tripling of both the "strong bipartisan consensus" and "strong partisan dissensus" categories. These results provide even stronger support for the hypothesis that the level of consensus declines as one moves from more general questions to specific policies and decisions. 
Table 12. Consensus and Dissensus in the 1988 Foreign Policy Leadership Survey, Using Cutting Points Based on Two-thirds Rather Than Three-fourths Majorities

\begin{tabular}{|c|c|c|c|c|c|c|}
\hline \multirow[b]{2}{*}{ Subject [Table] } & \multicolumn{3}{|c|}{ Consensus } & \multicolumn{3}{|c|}{ Dissensus } \\
\hline & Strong & Moderate & Weak & $\begin{array}{l}\text { Within/ } \\
\text { Between }\end{array}$ & Partisan & $\begin{array}{c}\text { Strong } \\
\text { Partisan }\end{array}$ \\
\hline \multicolumn{7}{|l|}{ General/philosophical } \\
\hline Causes of war [2] & 6 & 2 & 0 & 1 & 0 & 0 \\
\hline Approaches to peace [3] & 3 & 2 & 1 & 1 & 1 & 0 \\
\hline \multicolumn{7}{|l|}{ The U.S. in world affairs } \\
\hline Roles and interests [4] & 3 & 1 & 0 & 3 & 0 & 0 \\
\hline Goals of U.S. policy [5] & 6 & 6 & 1 & 1 & 2 & 0 \\
\hline \multicolumn{7}{|l|}{ The global environment } \\
\hline International system [6] & 1 & 2 & 0 & 0 & 1 & 2 \\
\hline Adversaries [7] & 4 & 3 & 0 & 0 & 4 & 0 \\
\hline Foreign policy processes [8] & 1 & 1 & 0 & 0 & 2 & 1 \\
\hline Means and instruments [9] & 1 & 3 & 1 & 0 & 4 & 1 \\
\hline Specific policies [10] & 5 & 1 & 0 & 0 & 4 & 6 \\
\hline
\end{tabular}

\section{TECHNICAL APPENDIX}

The decision to establish cutting points at 25 percent intervals in Table 1, although certainly not beyond possible objections, requires little additional explanation. It may be less clear how the cutting points in Versions III and IV of Table 1, which take into account the intensity of agreement or disagreement, were established. How does the 75 percent agreement level in Table 1 that defines the highest level of consensus compare to the cutting point of 0.375 in Version III?

When the frequencies of "agree strongly" and "agree somewhat" responses are equal, and the same is true of "disagree somewhat" and "disagree strongly" - that is, when intensity of agreement or disagreement essentially does not affect the results - then the 75 percent level in Table 1 is precisely the same as 0.375 in Version III. The distribution across those four categories is 37.5 percent, 37.5 percent, 12.5 percent, and 12.5 percent, respectively, resulting in an agreement level of 75 percent for purposes of Table 1, or an agreement index score of $0.375(.375 \times 1.0+.375 \times$ $0.5-\{.125 \times 0.5+.125 \times 1.0\})$. Of course, few cases will result in such a distribution, and many others will result in an index score of 0.375 . The minimal level of agreement ( 58.33 percent) to reach an index score of at least 0.375 occurs when all those who agree do so "strongly," while respondents who disagree are only "moderately" opposed.

A similar question might be raised about the relationship of the scoring in Versions II and IV of Table 1 for questions that offer response options such as "very important," "somewhat important," and "not at all important." The minimum "very important" responses needed to reach the 0.75 index level occurs when equal numbers in the entire sample respond "very important" and "somewhat important." 


\section{NOTES}

This research was supported by National Science Foundation Grant SES-87-22646. I would like to thank Richard Boyd, James Rosenau and Eugene Wittkopf for helpful comments on an earlier draft of this paper, which was presented at the 1991 Annual Meeting of the International Society of Political Psychology; the editors and several anonymous reviewers of ARP for suggested revisions; and Rita Dowling, Dan Harkins, and Elizabeth Rogers for various types of assistance.

${ }^{1}$ The extent, or even the existence, of a post-world War II foreign policy consensus itself has been the subject of a vigorous debate.

${ }^{2}$ However, Prothro and Grigg elsewhere $(1960,286)$ appear to have established a less demanding criterion: "If we keep in mind that a 50-50 division represents a total absence of consensus, then degrees of agreement ranging from 25 to 75 percent can be understood as closer to the total absence of consensus (50 percent agreement) than to its perfect realization (100 percent agreement)."

${ }^{3}$ In a later article on conformity and deviation, McClosky appears to accept a somewhat more relaxed threshold point of 70 percent (DiPalma and McClosky 1970, 1059).

${ }^{4}$ This clearly was the premise behind the advice, offered by Secretary of State William Seward to President Lincoln on April 1, 1861, to precipitate a crisis - and perhaps a war-with Spain, France or England as a means of reunifying the country.

${ }^{5}$ Each of these four studies surveyed approximately four thousand American leaders. Their names were drawn from general directories such as Who's Who in America and Who's Who of American Women, as well as more specialized directories of occupational groups that tend to be underrepresented in Who's Who. The surveys, conducted by means of mailed questionnaires, elicited response rates ranging from 53 percent to 63 percent. For more details on the sampling designs, questionnaires, and some of the results, see Holsti and Rosenau (1984) and Holsti (1990).

${ }^{6}$ Independents and members of third parties are excluded from this scheme. However, evidence from the four Foreign Policy Leadership surveys to date indicate that responses of independents almost invariably fall between those who identify themselves as Republicans or Democrats. For evidence of the importance of partisanship in providing a framework for dealing with issues, see Hamill et al. (1985).

${ }^{7}$ If more response options are available, the scoring can be adapted to maintain a scale of 0.00 to 1.00. For example, if two intermediate options are offered, "somewhat important" can be scored as 0.67 and "slightly important" as 0.33 .

${ }^{8}$ Several efforts of this type are described in Chittick and Billingsley (1989); Hinckley (1992); Holsti and Rosenau (1990); Hurwitz and Peffley (1987); and Wittkopf (1990).

${ }^{9}$ This objection has been made in a private communication from Eugene R. Wittkopf.

\section{REFERENCES}

Chase, James. 1978. Is a Foreign Policy Consensus Possible? Foreign Policy 57: 1-16.

Chittick, William, and Keith Billingsley 1989. The Structure of Elite Foreign Policy Beliefs. Western Political Quarterly 42: 201-224.

Cohen, Bernard. n.d. Unpublished manuscript.

Economist, The. 1993. Comrades. 27 February: 42-43.

Conovan, Francis 1961. The Level of Consensus. Modern Age 5: 239-250.

DiPalma, Guiseppe and Herbert McClosky. 1970. Personality and Conformity: The Learning of Political Attitudes. American Political Science Review 64: 1054-1073.

Graham, George J., Jr. 1984. Consensus. In Giovoni Sartori, ed., Social Science Concepts. Beverly Hills, CA: Sage. 
Graham, Thomas W. 1989. The Politics of Failure: Strategic Nuclear Arms Control, Public Opinion, and Domestic Politics in the United States-1945-1980. Ph.D. dissertation, Massachusetts Institute of Technology.

Hamill, Ruth C., Milton Lodge, and Frederick Blake. 1985. The Breadth, Depth, and Utility of Class, Partisan, and Ideological Schemata. American Journal of Political Science 29: 850-870.

Hinckley, Ronald. 1992. People, Polls, and Policy-Makers. New York: Lexington Books.

Holsti, Ole R. 1990. The Domestic and Foreign Policy Beliefs of American Leaders: 1988. Final Report to the National Science Foundation on Grant Number SES-87-22646.

and James N. Rosenau. 1990. The Structure of Foreign Policy Attitudes Among American Leaders. Journal of Politics 52: 91-128.

1984. American Leadership in World Affairs: Vietnam and the Breakdown of Consensus. London: Allyn \& Unwin.

Hurwitz, Jon, and Mark Peffley. 1987. How Are Foreign Policy Attitudes Structured: A Hierarchical Model. American Political Science Review 52: 94-128.

Key, V.O., Jr. 1961. Public Opinion and American Democracy. New York: Alfred A. Knopf.

McClosky, Herbert. 1964. Consensus and Ideology in American Politics. American Political Science Review 58: 361-382.

Newcomb, Theodore M. 1959. The Study of Consensus. In R.K. Merton, ed., Sociology Today. New York: Basic Books.

Prothro, James and Charles M. Grigg. 1960. Fundamental Principles of Democracy: Bases of Agreement and Disagreement. Journal of Politics 22: 276-292.

Safire, William. 1978. Safire's Political Dictionary. New York: Random House.

Waltz, Kenneth. 1959. Man, The State and War. New York: Columbia University Press.

Webster's Dictionary. 1986. Springfield, MA: Merriam-Webster.

Willhoite, Fred H., Jr. 1963. Political Order and Consensus: A Continuing Problem. Western Political Quarterly 16: 294-304.

Wittkopf, Eugene R. 1990. Faces of Internationalism: Public Opinion and American Foreign Policy. Durham, NC: Duke University Press. 
